\title{
Toll-like receptors in the brain of mice following infection with Acanthamoeba spp.
}

\author{
Agnieszka Wojtkowiak-Giera $^{1} \cdot$ Monika Derda $^{1} \cdot$ Agnieszka Kolasa-Wolosiuk $^{2}$. \\ Edward Hadaś $^{1}$ • Danuta Kosik-Bogacka ${ }^{3}$ - Piotr Solarczyk ${ }^{1}$ • Pawel P. Jagodziński ${ }^{4}$. \\ Elżbieta Wandurska-Nowak ${ }^{1}$
}

Received: 16 November 2015 /Accepted: 28 July 2016 /Published online: 11 August 2016

(C) The Author(s) 2016. This article is published with open access at Springerlink.com

\begin{abstract}
The Toll-like receptors (TLRs) of the innate immune system play an important role in the recognition of pathogens such as bacteria, viruses, fungi, and parasites. In this study, we examined the changes in the level of expression of TLR2 and TLR4 mRNA and protein in the brains of mice infected with Acanthamoeba spp. The Acanthamoeba strains were isolated from a patient with Acanthamoeba keratitis (AK) (Ac55) and Malta Lake (Ac43). In the brain isolated from mice at 2 days post-infection (dpi) with Acanthamoeba strains Ac55 and Ac43, mRNAs for TLR2 and TLR4 were significantly more strongly expressed in comparison with the uninfected mice. In Acanthamoeba-infected mice, TLR2 and TLR4 expression was detected in neurons, glial cells, and endothelial cells within the neocortex. These receptors showed more intense expression in ependymocytes of the choroid plexus of infected mice at $2 \mathrm{dpi}$. Increased levels of TLR2 and TLR4 mRNA expression in infected mice suggest the involvement of these TLRs in the recognition of Acanthamoeba spp. pathogen-associated molecular patterns (PAMPs).
\end{abstract}

Monika Derda

mderda@ump.edu.pl

1 Department of Biology and Medical Parasitology, Poznan University of Medical Sciences, 10 Fredry Street, 61-701 Poznan, Poland

2 Department of Histology and Embryology, Pomeranian Medical University, 71 Powstancow Wielkopolskich Street, 70-111 Szczecin, Poland

3 Department of Biology and Medical Parasitology, Pomeranian Medical University, 72 Powstancow Wielkopolskich Street, 70-111 Szczecin, Poland

4 Department of Biochemistry and Molecular Biology, Poznan University of Medical Sciences, 6 Swiecickiego Street, 60-781 Poznań, Poland
Keywords TLR2 $\cdot$ TLR4 $\cdot$ Toll-like receptors $\cdot$ Q-PCR . Immunohistochemistry $\cdot$ Acanthamoeba $\mathrm{spp}$. Brain $\cdot$ Mouse

\section{Introduction}

Acanthamoeba spp. are free-living amoebae (FLA) found in several natural habitats, including lakes, rivers, swimming pools, thermal baths, tap water, sewage, humid soils, and dust (Khan, 2006).

Traditional taxonomy of Acanthamoeba has used morphological characteristics of cysts and trophozoites (Booton et al. 2005). However, genetic studies have led to the identification of 18 genotypes (T1-T18) based on rRNA gene sequences (Qvarnstrom, et al. 2013). The T4 genotype has been frequently reported as a predominant cause of AK (Niyyati et al. 2009).

Acanthamoeba spp. can infect humans and animals as opportunistic pathogens and cause severe diseases, including amebic Acanthamoeba keratitis (AK), a painful sightthreatening infection of the cornea, and granulomatous amebic encephalitis (GAE), a fatal disease of the central nervous system (CNS), in immunocompromised hosts (Martinez \& Visvesvara, 1997; Visvesvara et al. 2007). The important clinical symptoms of GAE are headache, fever, behavioral changes, lethargy, stiff neck, aphasia, ataxia, nausea, cranial nerve palsies, confused state, seizures, and coma, which finally lead to death. Pathological findings include hemorrhagic necrosis, fibrin thrombi, and inflammation (Marciano-Cabral \& Cabral 2003). The intensity of symptoms and histological changes in the host may be a result of many factors including the immunocompetence of the host and the virulence of amoebae. Experimental studies have shown that the properties of pathogenic free-living amoebae and the intensity of histological changes in organs depend on the virulence of the strain (Rucka, 1974) and, on the other hand, the duration of infection 
(Gieryng et al. 1993). In mice infected with different strains of Acanthamoeba spp., Górnik et al. (2005) demonstrated that the changes in intensity in the brain depend on the virulence of the strain.

Acanthamoeba spp. infections of the skin, nasal passages, lung, and brain are also documented in patients with immunodeficiency disease (Martinez \& Visvesvara 1997; MarcianoCabral \& Cabral, 2003). Furthermore, several studies strongly suggest that Acanthamoeba spp. can act as reservoir hosts for other pathogenic viruses, bacteria, and fungi (Barker \& Brown 1994; Scheid et al. 2008; Gaze et al. 2011; Scheid \& Schwarzenberger 2012). In addition, although GAE occurs in healthy people, immunocompromised or debilitated patients due to HIV infection, diabetes, immunosuppressive therapy, malignancies, malnutrition, and alcoholism are particularly at risk (Visvesvara et al. 2007).

The immune defense mechanisms that operate against Acanthamoeba have not been well characterized. It was found that in the host defense mechanisms against Acanthamoeba spp., both innate and acquired immunities play a role (Cursons et al. 1980; Marciano-Cabral \& Cabral 2003). McClellan (2002) found that trophozoites as well as cysts are recognized by the immune system of the host. The innate immunity was the first line of defense against Acanthamoeba infection (Ferrante \& Rowan-Kelly 1983). Ferrante and Abell (1986) as well as Stewart et al. (1992) demonstrated in vitro killing of trophozoites of Acanthamoeba spp. in the presence of neutrophils and macrophages. However, activation in response to infection with Acanthamoeba and the role of antibodies are not known (Marciano-Cabral \& Cabral 2003). Antibodies may prevent attachment to host cells, inhibit the motility of amoebae, or neutralize ameba cytotoxic factors (Cursons et al. 1980; Ferrante \& Abell 1986; Stewart et al. 1994; Marciano-Cabral \& Toney 1998).

The pathogenesis of infections by Acanthamoeba, including the cellular processes and molecules involved in the recognition and adhesion to the host tissues, is little known. However, Soto-Arredondo et al. (2014) suggested that glycoproteins on the surface of Acanthamoeba trophozoites interact with and recognize receptors on the host cell.

The innate immune response in the brain and other tissues is initiated via recognition of pathogen-associated molecular patterns (PAMPS) by pathogen recognition receptors (PRRs) such as the Toll-like receptors (TLRs) (Creagh \& O'Neil 2006). To date, 13 TLRs have been identified in mammals, each of which recognizes specific PAMPS or host-derived damage-associated molecular patterns (DAMPS) (Roach et al. 2005; Akira et al. 2006). Signaling via the TLR pathway leads to the production of inflammatory cytokines, chemokines, adhesion molecules, and costimulatory molecules (Ospelt \& Gay 2010).

In this study, we examined two selected TLRs: 2 and 4. TLR2 and TLR4 are the best known transmembrane receptors and the most extensively analyzed members of the TLR family. The alteration of TLR2 and TLR4 expression in infected rats indicates the potential role of the innate immune system in the pathomechanism of Hymenolepis diminuta infection (Kosik-Bogacka et al. 2012; Kosik-Bogacka et al. 2013). Recent studies have shown that TLR2 is capable of recognizing ligands such as glycosylphosphatidylinositol (GPI) of Plasmodium falciparum, Toxoplasma gondii, Trypanosoma cruzi, Trypanosoma brucei, Leishmania major, and Leishmania donovani (Krishnegowda et al. 2005; Debierre-Grockiego et al. 2007; Chandra \& Naik 2008; Egan et al. 2009; Amin et al. 2012). The TLR4 ligands including lipophosphoglycans (LPG) of Leishmania spp. (Tuon et al. 2008) and lysophosphatidylserine of Schistosoma spp. (van der Kleij et al. 2002; Layland et al. 2007; Van der Kleij et al. 2004) confirm that the phosphatidylserine fraction of Schistosoma haematobium contains a TLR2 ligand as well as TLR4. Our previous study confirmed an increase in the level of expression of TLRs 2, 3, 4, and 9 during experimental hymenolepidosis (Kosik-Bogacka et al. 2012, 2013, 2014).

TLRs are predominantly expressed on immune cells but also on non-immune cells. TLR4 is also expressed in the brain cells, in particular parenchymal glial cells, microglia, astrocytes, and in neurons (Rolls et al. 2007; Acosta \& Davies 2008; Tu et al. 2011). However, the role of neuronal TLR4 in the central nervous system is unknown (Leow-Dyke et al. 2012). TLR2 is an important element of the brain innate immune response system. TLR2 is also expressed on microglia, astrocytes, neurons, and endothelial cells (Laflamme et al. 2001; Bsibsi et al. 2002), and similarly, the functional significance of this receptor is still unknown (Kielian et al. 2005). Therefore, the aim of this study was to characterize for the first time the expression of TLR2 and TLR4 in the brain of Acanthamoeba spp.-infected mice using quantitative real-time polymerase chain reaction (Q-PCR) and immunohistochemical staining (IHC). The Acanthamoeba spp. were isolated from a patient with AK (Ac55) and Malta Lake (Ac43).

\section{Materials and methods}

\section{Acanthamoeba spp.}

The amoebae isolated from a patient with AK (strain Ac55) and from environmental samples of water from Malta Lake in Poznań, Poland (strain Ac43), were cultured on a non-nutrient agar covered by bacteria Enterobacter aerogenes at a temperature of $28{ }^{\circ} \mathrm{C}$. After 2-3 days of culture, amoebae were washed and used for infection or research.

\section{Genotyping of Acanthamoeba}

The DNA amplification was performed using genus-specific primers previously described by Schroeder et al. (2001). A set 
of primers that included the forward JDPI ( $5^{\prime}$ GGCCCAGA TCGTTTACCGTGAA' 3 ) and the reverse primer JDP2 was used (5'TCTCACAAGCTGCTAGGGAGTCA'3) for genetic characterization targeting an $\sim 450$-bp fragment of the Acanthamoeba 18S rRNA gene. Amplification involved use of a $25-\mu 1$ suspension of the following reagents: $2.5 \mathrm{mM}$ $\mathrm{MgCl}_{2}, 0.6-1 \mu \mathrm{M}$ of each primer, $0.2 \mathrm{mM}$ of each deoxynucleotide triphosphate, and $0.5 \mathrm{U}$ of AmpliTaq Gold DNA polymerase. A clinical isolate of $A$. castellanii belonging to the T4 genotype isolated from a keratitis patient (ATCC 00000) was used as a positive control. A negative control consisting of a reaction mixture without a DNA template was included. PCR was carried out using a GeneAmp 2400 thermocycler. Two PCR products were cleaned and sequenced in both directions with the same set of primers. Sequencing was performed with BigDye Terminator v3.1 on an ABI Prism 3130XL Analyzer (Applied Biosystems, USA). Trace files were checked and edited using FinchTV 1.3.1 (Geospiza Inc., Seattle, USA). Contigs were aligned and manually assembled in GeneDoc v. 2.7.000 (Nicholas et al. 1997). Next, the gene sequence fragments of the Acanthamoeba isolates were compared with the reference sequences deposited in GenBank (National Center for Biotechnology Information).

\section{Animals}

BALB/c mice, 2-3 weeks old, body weight 10-15 g, were bred and housed in our animal laboratory, which ensured approximately constant temperature, humidity, and ad libitum access to standardized granulated food and water. Mice lightly anesthetized were intranasally infected with one drop of suspension containing $2 \times 10^{4}$ amoebae. Control mice were given the same volume of physiological solution. After inoculation, the animals were monitored constantly.

The experimental material consisted of brains from mice infected with two different strains of Acanthamoeba isolated from a patient with $\mathrm{AK}$ and from environmental samples.

The mice $(n=54)$ were divided into nine groups:

- Control group $0(n=6)$ - uninfected, 0 days postAcanthamoeba infection (0 dpi)

The mice infected by Acanthamoeba strain Ac55:

- Group I $(n=6)-2$ dpi

- Group II $(n=6)-4$ dpi

- Group III $(n=6)-16$ dpi

- Group IV $(n=6)-30 \mathrm{dpi}$

The mice infected by Acanthamoeba strain Ac43:

- Group I' $(n=6)-2$ dpi

- Group II' $(n=6)-4$ dpi
- Group III' $(n=6)-16$ dpi

- Group IV' $(n=6)-30$ dpi

The section infected mice with Acanthamoeba at 2, 4, 16, and $30 \mathrm{dpi}$, depending on the symptoms of infection such as lack of mobility, depression, turning in circles, tousled (matted) hair, anorexia, or emaciation (wasting).

The study was approved by the Local Ethics Committee for Scientific Experiments on Animals in Poznań (Poland).

\section{Evaluation of infection of animals}

Fragments of brains were collected from experimental animals at 2, 4, 16, and $30 \mathrm{dpi}$.

Sterile collected tissues were applied on $1.5 \%$ agar plates covered with a layer of $E$. aerogenes. The agar plates were incubated at $25^{\circ} \mathrm{C}$. Growth of Acanthamoeba on agar plates was observed by microscope at $\times 40-100$ magnification. Animals were regarded as infected when the presence of amoeba was identified on the agar.

\section{Isolation of RNA and conversion of cDNA by reverse transcription}

The expression of TLR 2 and TLR 4 genes at the mRNA level in brains in mice of five groups (control and 2, 4, 16, $30 \mathrm{dpi}$ ) was examined using reverse transcription polymerase chain reaction (RT-PCR). The brains were homogenized in liquid nitrogen, and total RNA was isolated according to the manufacturer's instructions (Qiagen, Germany). One microgram of RNA from segments of lungs was reverse transcribed with an oligo (dT) primer in a $20-\mu 1$ reaction (first-strand cDNA synthesis using M-MLV RT kit; Invitrogen, CA) to obtain cDNA. Successful cDNA conversions were confirmed by amplification using conventional PCR (GeneAmp PCR System 2400, Applied Biosystems).

\section{Real-time PCR}

The expression of TLR2 and TLR4 genes in fragments of brain was measured by Q-PCR. This method enables both detection and quantification of gene expression at the mRNA level. Q-PCR was carried out in a LightCycler realtime PCR detection system from Roche Diagnostic GmbH (Mannheim, Germany) using SYBR Green I as detection dye, and target cDNA was quantified using a relative quantification method using a calibrator. The calibrator was prepared as a cDNA mix from all samples, and successive dilutions were used to create a standard curve as described in the Relative Quantification Manual, Roche Diagnostics GmbH (Mannheim, Germany). The housekeeping gene PBGD was amplified as the reference gene for mRNA quantification. The quantity of TLR2 and TLR4 transcripts in each sample was 
standardized by the geometric mean of PBGD transcript level. For amplification, $1 \mu \mathrm{l}$ of total $(10 \mu \mathrm{l})$ cDNA solution was added to $5 \mu \mathrm{l}$ of LightCycler 480 DNA SYBR Green I Master (Roche) as well as primers for TLR2, TLR4, and PBGD. One RNA sample of each preparation was processed without RT reaction to provide a negative control in subsequent PCR series. Primers for TLR2 were forward 5'-AAA GAT GTC GTT CAA GGA GG-3' and reverse 5'-ATT TGA CGC TTT GTC TGA GG-3' (product-161 bp); TLR4 forward 5'-TTC TTC TCC TGC CTG ACA CC-3' and reverse 5'-CTT TGC TGA GTT TCT GAT CCA T-3' (product—94 bp); and PBGD forward 5'-TGG ACC TAG TGA GTG TGT TG-3' and reverse 5'-GGT ACA GTT GCC CAT CTT TC 3' (product$138 \mathrm{bp}$ ). Real-time data were collected and analyzed using the Excel program. The amounts of TLR2 and TLR4 mRNA are expressed as the multiplicity of these cDNA concentrations in the calibrator.

\section{Immunohistochemical staining}

Paraffin-embedded sections $(3-5 \mu \mathrm{m})$ of brains from mice infected with Acanthamoeba isolated from patients and from Malta Lake (control and 2, 4, 16, $30 \mathrm{dpi}$ ) were immunostained for visualization of TLR2 and TLR4 proteins.

Immunohistochemistry was performed using specific primary rabbit polyclonal antibodies against TLR2 and TLR4 (Santa Cruz Biotechnology, Inc., cat. no. sc-10739 and sc30002) in a final 1:500 dilution. Firstly, the deparaffinized sections were microwave irradiated in citrate buffer $(\mathrm{pH} 6.0)$ to heat induce epitope retrieval. After slow cooling to room temperature, slides were washed in PBS twice for $5 \mathrm{~min}$ and then incubated with primary antibodies overnight $\left(4{ }^{\circ} \mathrm{C}\right)$. On the next day, sections were stained with an avidin-biotin-peroxidase system with diaminobenzidine as the chromogen (Rabbit ABC Staining System, Santa Cruz Biotechnology, Inc., cat. no. sc-2018) in conformity with staining procedure instructions included. Sections were washed in distilled $\mathrm{H}_{2} \mathrm{O}$ and counterstained with hematoxylin. For a negative control, specimens were processed in the absence of primary antibodies. Positive staining was defined microscopically by visual identification of brown pigmentation. The IHC-stained sections were examined by light microscope (Leica, DM5000B, Germany).

\section{Statistical analysis}

The obtained results were analyzed statistically using Statistica 6.1 software. Arithmetic mean and standard deviation (SD) were calculated for each of the studied parameters. Twogroup testing was performed using Student's $t$ test. A value of $P<0.05$ was considered statistically significant.

\section{Results}

The macroscopic observation confirmed edema and hyperemia in the brain hemispheres of mice infected with Acanthamoeba.

\section{Genotyping of Acanthamoeba}

The DNA was isolated from two Acanthamoeba-positive samples. Amplicons of the fragment of $18 \mathrm{~S}$ rRNA gene were obtained from the Acanthamoeba Ac43 and Ac55 isolates from the water and corneal scrape, respectively. The results showed that sequences obtained from Acanthamoeba Ac43 isolates shared $100 \%$ identity to the sequences from the isolates of Acanthamoeba obtained from meadow soil (KF928953), gill tissue (HM363628), air conditioner (GQ397470), and river water (EU273824). The comparison of the sequence at the same molecular marker of the Acanthamoeba Ac55 isolate from the human with the sequences deposited in GenBank also showed $100 \%$ identity to the sequences of this gene of the parasite isolated from infected liver of pheasant Tragopan temminckii (GQ889265), corneal (KF318460, DQ087297) and contact lens (DQ087296) scrapings, and an environmental sample (EU377583) (Table 1).

The Acanthamoeba sequences from the isolates obtained from Malta Lake, Poznan (Ac43) and corneal scraping (Ac55) were deposited in GenBank (NCBI) under accession numbers KP120879 and KP120880, respectively.

\section{Expression of TLR2 and TLR4 genes}

This study showed that the levels of mRNA expression of Toll-like receptor (TLR2 and TLR4) genes in the control group (uninfected mice) were very similar (Figs. 1 and 2).

In the brain of mice infected by Acanthamoeba strains of Ac55 and Ac43, it was observed that the level of mRNA expression of TLR 2 statistically increased only at 2 dpi, and at $4 \mathrm{dpi}$, it was higher but without statistical significance, whereas at 16 and $30 \mathrm{dpi}$, it was at a similar level compared with the control group (Fig. 1a, b).

The levels of mRNA expression of TLR4 in the brains from the infected mice statistically increased only at $2 \mathrm{dpi}$, whereas at 4, 16, and $30 \mathrm{dpi}$, it was at a similar level compared with uninfected mice (Fig. 2a, b).

In the brains of mice infected by Acanthamoeba spp. isolated from a patient with Acanthamoeba keratitis (Ac55) and Malta Lake (Ac43), the levels of expression of TLR2 were statistically higher than the levels of expression of TLR4.

\section{Immunohistochemical staining}

The results of the immunohistochemical reactions, presented in Fig. 3c, d, g, h, k, 1, o, p, show that brains (neocortex) of mice 
Table 1 Results of genotyping of Acanthamoeba sp. from water and clinical sample

\begin{tabular}{|c|c|c|c|c|c|}
\hline \multirow[t]{2}{*}{ Sampling } & \multirow[t]{2}{*}{ Isolate, accession no. } & \multicolumn{4}{|c|}{ Published sequences in the GenBank } \\
\hline & & Accession no. & Sampling, isolate & Region of origin & References \\
\hline \multirow[t]{4}{*}{ Malta Lake, Poznan } & \multirow[t]{4}{*}{ Ac43, KP120879 } & KF928953 & $\begin{array}{l}\text { High altitude meadow soil, Acanthamoeba } \\
\text { sp., Tib121 }\end{array}$ & China & Geisen et al. (2014) \\
\hline & & HM363628 & $\begin{array}{l}\text { Gill tissue, rainbow trout, Acanthamoeba } \\
\text { sp., GERF3 }\end{array}$ & Germany & Dyková et al. (2010) \\
\hline & & GQ397470 & $\begin{array}{l}\text { Air conditioner water, Acanthamoeba } \\
\text { sp., AcaVN08 }\end{array}$ & Slovakia & Nagyova et al. (2010) \\
\hline & & EU273824 & $\begin{array}{l}\text { River water, upstream from a drinking } \\
\text { water production plant, Acanthamoeba } \\
\text { sp., CRIB-22 }\end{array}$ & France & Thomas et al. (2008) \\
\hline \multirow[t]{5}{*}{ Corneal scrape } & \multirow[t]{5}{*}{ Ac55, KP120880 } & GQ889265 & $\begin{array}{l}\text { CDCV600, liver of a Temminck's tragopan, } \\
\text { Acanthamoeba sp., genotype: T4 }\end{array}$ & USA & Visvesvara et al. (2010) \\
\hline & & KF318460 & $\begin{array}{l}\text { Corneal surface tissue, Acanthamoeba sp., } \\
1 \text { FRC-2013 }\end{array}$ & Brazil & Mafra et al. (2013) \\
\hline & & EU377583 & Biofilm, Acanthamoeba sp., CRIB53 & Switzerland & Corsaro et al. (2009) \\
\hline & & DQ087296 & $\begin{array}{l}\text { Contact lenses and contact lens case, } \\
\text { Acanthamoeba sp., S6 }\end{array}$ & France & Yera et al. (2008) \\
\hline & & DQ087297 & $\begin{array}{l}\text { Corneal scraping, Acanthamoeba } \\
\text { sp., 222BAL }\end{array}$ & France & Yera et al. (2007) \\
\hline
\end{tabular}

infected with Acanthamoeba exhibited changes in TLR2 and TLR4 (Fig. 3e, f, i, j, m, n, q, r) intensity in comparison to the control group (Fig. 3a, b).

In control mice brains, both Toll-like receptors were expressed in epithelium of neural blood vessels (Fig. 3a, b; red arrows); TLR2 was sporadically observed in neurons and glial cells (black and blue arrows, respectively). In these groups, TLR4 expression was slightly more intensive than TLR2.

In the neocortex of mice infected by Acanthamoeba strain Ac55, TLR2 (Fig. 3c, g, k, 1, o) was located mainly in neurons (black arrows); sporadically glial cells (blue arrow) and also infrequently endothelial cells of capillaries (red arrow) were low TLR2-positive. The TLR2 immunoexpression was most intense at 2 and 4 dpi (Fig. 3c, g), and the immunointensity decreased during the time of infection. At 16 and $30 \mathrm{dpi}$ (Fig. 3k, o), the level of TLR2 expression was quite similar to the control group (Fig. 3a) but appeared to be lower.

A brown pigmentation indicated that TLR4 immunohistochemical staining within the neocortex of brains of mice infected by Acanthamoeba strain Ac55 (Fig. 3e, i, m, q) was the highest at 2 dpi (Fig. 3e) and markedly decreased during the time of infection (Fig. 3i, m, q). The immunoexpression was observed in neurons (black arrows), glial cells (blue arrows), and capillaries (red arrows). The number of TLR4-positive cells (neurons, glial, and endothelial) was higher than in TLR2 immunostaining experiment.

In the neocortex of mice infected by Acanthamoeba strain Ac43, TLR2 (3, D, H, L, P) was located mainly in neurons (blue arrows) and sometimes in glial cells (blue arrows) and endothelial cells (red arrows). The highest expression was noted at 2 dpi (Fig. 3d), lower at 4 dpi (Fig. 3h), and lower, similar to the control, at 16 and $30 \mathrm{dpi}$ (Fig. 31, p).

TLR4 expression in neocortex of mice infected by Acanthamoeba strain Ac43 (Fig. 3f, j, n, r) was analogous to TLR4 expression within the group of mice infected by Acanthamoeba strain Ac55. The highest expression was observed at 2 dpi (Fig. 3f) and was much lower at the subsequent days post-infection (Fig. 3j, n, r). Neurons (black arrows) and glial (blue arrows) and endothelial (red arrows) cells were immunopositive.

The changes of immunoexpression of Toll-like receptors were also observed in ependymocytes of the choroid plexus (Fig. $4 \mathrm{a}-\mathrm{h}$, black arrows). The highest TLR2 and TLR4 expression levels were at 2 dpi (Fig. 4a-d), decreasing during the time of infection and reaching a minimum at $30 \mathrm{dpi}$ (Fig. 4e-h). TLR expression was much more intense in choroidal ependymocytes of mice infected by Acanthamoeba strain Ac43 (Fig. 4b, d, f, h) than Ac55 (Fig. 4a, c, e, g). During the period of infection, TLR expression in ependymocytes fell, but in connective tissue of the choroid plexus, there appeared immunopositive cells (Fig. 4f, g, h; blue arrows), possibly dendritic cells.

\section{Discussion}

The results of this study indicate a neurotropic character of both strains of Acanthamoeba (Ac43 and Ac55). In all the infected mice, Acanthamoeba spp. were confirmed in the 

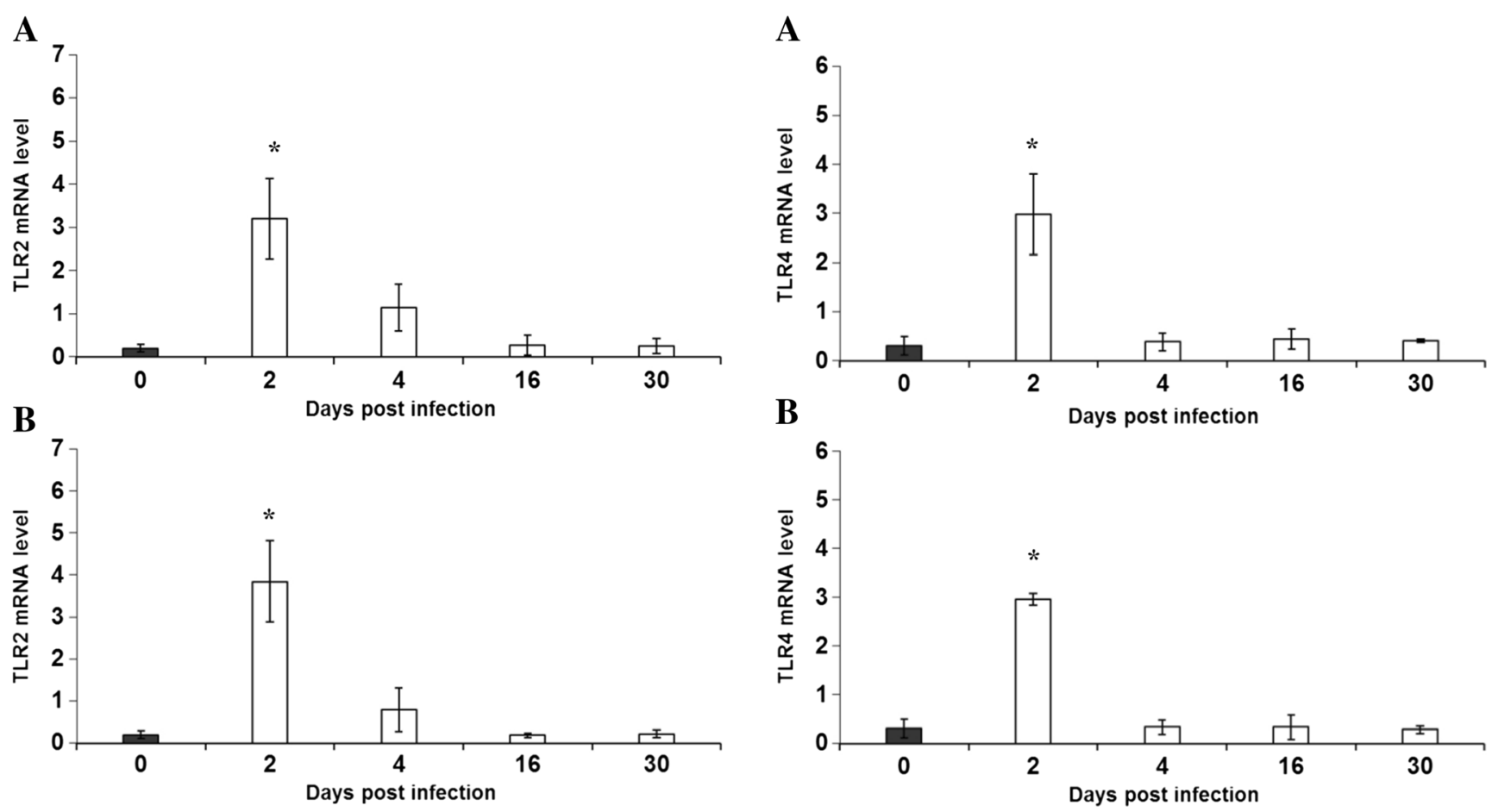

Fig. 1 Expression of TLR2 gene at the mRNA level in brains isolated from uninfected and Acanthamoeba-infected mice from patient with Acanthamoeba keratitis (strain Ac55; a) and Malta Lake (strain Ac43; b). Brains were dissected from mice at 2, 4, 16, and 30 dpi. Expression level of TLR2 gene was determined by Q-PCR relative quantification analysis evaluated using a calibrator (cDNA mix from all samples). The quantify of TLR2 transcript in each sample was standardized to the amount of PBGD cDNA as the internal control. The amounts of TLR2 mRNA are expressed as the multiplicity of these cDNA concentrations in the calibrator. Each sample was determined in triplicate. Data represent mean $\pm \mathrm{SD}$ and are representative of groups of six animals in an experiment. $* P<0.05$, compared with the control value derived from uninfected mice (Student's $t$ test)

brain. Also, Kasprzak et al. (1974) indicate the brain as the primary site of infection by intranasal inoculation. The most common microscopic changes in the brain include blood effusion resulting from damage to the capillary walls (Rucka 1974; Gieryng and Gieryng 1987; Górnik et al. 2005). Górnik et al. (2005) found, in parts of the meninges and perivascular space of mice infected with Acanthamoeba spp., trophozoites of Acanthamoeba as well as neutrophils, macrophages, plasma cells, and single multinucleate giant cells.

This study reports the first documentation of the expression of TLR2 and TLR4 mRNA and protein in the brains of Acanthamoeba spp.-infected mice. The CNS is an immunologically unique organ because of the presence of the bloodbrain barrier (BBB) and the absence of a classically defined lymphatic drainage system (Mishra et al. 2006). Parasitic infection of the CNS (such as malaria, African trypanosomiasis, neurocysticercosis, and amoebic encephalitis) is a major cause of mortality worldwide, second to HIV infection (Mishra et al. 2009). During infection, cells of the CNS have the ability to produce inflammatory mediators such as chemokines,

Fig. 2 Expression of TLR4 gene at the mRNA level in brains isolated from uninfected and Acanthamoeba-infected mice from patient with Acanthamoeba keratitis (strain Ac55; a) and Malta Lake (strain of Ac43; b). Brains were dissected from mice at 2, 4, 16, and 30 dpi. Expression level of TLR4 gene was determined by Q-PCR relative quantification analysis evaluated using a calibrator (cDNA mix from all samples). The quantify of TLR4 transcript in each sample was standardized to the amount of PBGD cDNA as the internal control. The amounts of TLR 4 mRNA are expressed as the multiplicity of these cDNA concentrations in the calibrator. Each sample was determined in triplicate. Data represent mean $\pm \mathrm{SD}$ and are representative of groups of six animals in an experiment. $* P<0.05$, compared with the control value derived from uninfected mice (Student's $t$ test)

adhesion molecules and cytokines, and costimulatory molecules during infection (Takeda et al. 2001; Dabbagh \& Lewis 2003; Chavarria \& Alcocer-Varela 2004). In the brain, TLRs, including TLR2 and TLR4, are expressed on microglia, astrocytes, and oligodendrocytes (Bsibsi et al. 2002a, 2002b; Bowman et al. 2003; Olson \& Miller 2004). However, in neurons, TLR2 and TLR4 are expressed (Tang et al. 2007). The TLR family of proteins plays an important role in host innate immunity (Hoebe et al. 2004). Once engaged, signaling through TLRs starts from the Toll/interleukin-1 receptor (TIR) domain (Medzhitov 2001) and involves one of four adaptor protein: myeloid differentiation factor 88 (MyD88), MyD88-adaptor-like/TIR-associated proteins (MAL/TIRAP), Toll-receptor-associated activator of interferon (TRIF), and Toll-receptor-associated molecule (TRAM) (Mishra et al. 2009). Moreover, it has been proposed that TLRs control the switch from the innate to the adaptive immune response (Yarovinsky et al. 2005).

In this study, we observed a statistically increased level of expression of TLR 2 as well as TLR 4 mRNA at 2 dpi in 
Fig. 3 Immunoexpression of Toll-like receptor 2 (TLR2) (a, c $\mathbf{d}, \mathbf{g}, \mathbf{h}, \mathbf{k}, \mathbf{l}, \mathbf{o}, \mathbf{p})$ and Toll-like receptor 4 (TLR4) (b, e, f, i, j, m, $\mathbf{n}, \mathbf{q}, \mathbf{r})$ within neocortex of control $(\mathbf{a}, \mathbf{b})$ and mice infected with Acanthamoeba spp. isolated from patient with Acanthamoeba keratitis strain $\operatorname{Ac55}(\mathbf{c}, \mathbf{e}, \mathbf{g}, \mathbf{i}, \mathbf{k}$, $\mathbf{m}, \mathbf{o}, \mathbf{q})$ and from Malta Lake strain Ac43 (d, f, h, j, l, n, p, r) in 2, 4, 16, and 30 dpi. Exemplary immunopositive cells: neuronsblack arrows; glial cells — blue arrows; endothelial cells of neural capillaries - red arrows. Intensity of IHC reaction was highest in the 2-dpi group and decreased during the period of infection. Objective magnification $\times 40$

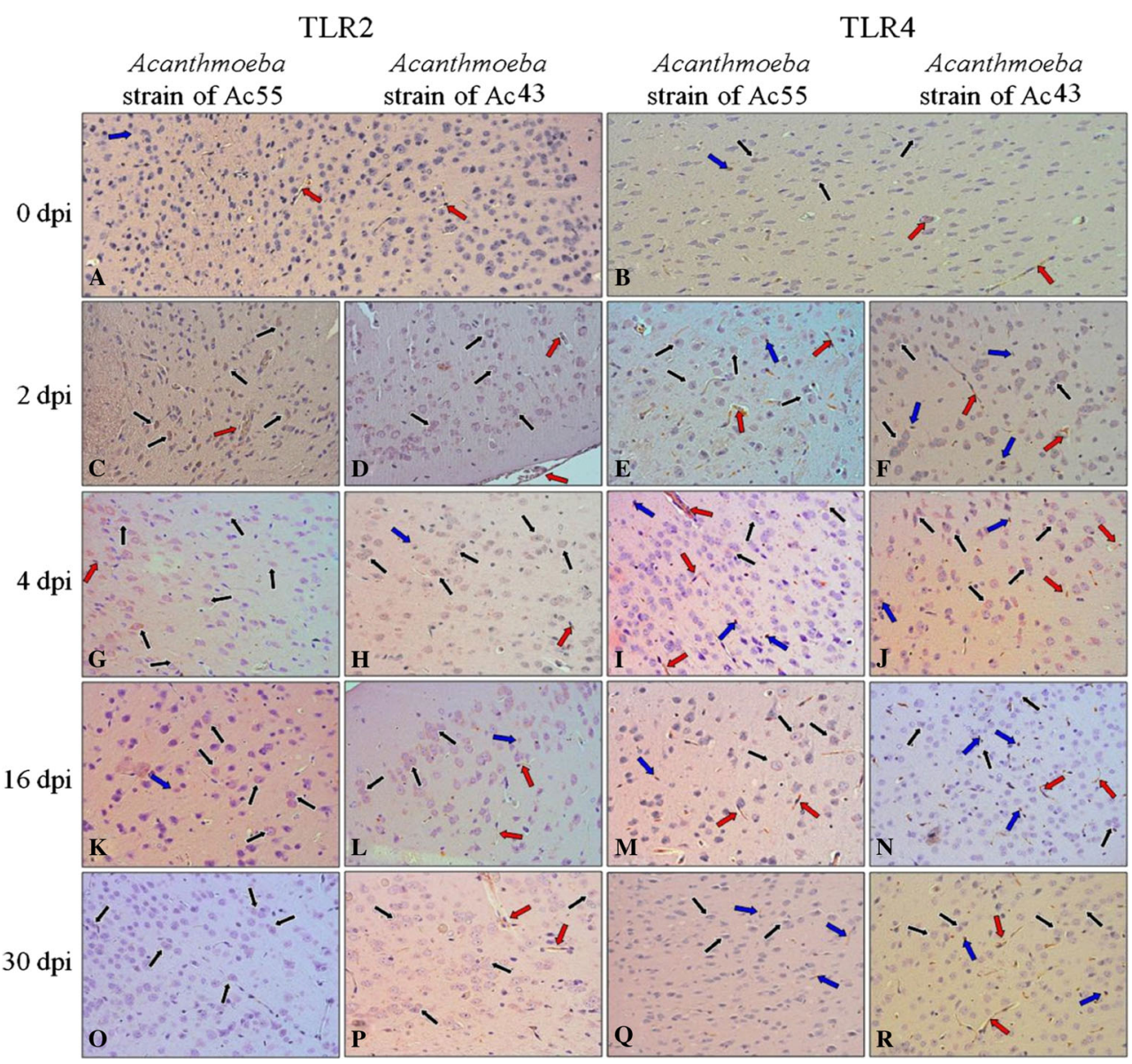

the brains of mice infected with two different strains of Acanthamoeba. In Acanthamoeba-infected mice, TLR2 and TLR4 expression was detected in neurons, glial cells, and endothelial cells of the neocortex. It is also interesting that TLR2 and TLR4 were more intensively expressed in ependymocytes of the choroid plexus of infected mice at 2 dpi.

Fig. 4 Immunoexpression of Toll-like receptor 2 (TLR2) (a, b, e, f) and Toll-like receptor 4 (TLR4) (c, d, g, h) within choroid plexus of mice infected with Acanthamoeba spp. isolated from patient with Acanthamoeba keratitis (strain Ac55) (a, c, e, g) and from Malta Lake (strain Ac43) (b, d, f, h) at 2 and 30 dpi. Choroidal ependymocytesblack arrows; interstitial cells (possibly dendritic cells) - blue arrows. Intensity of IHC reaction was the highest in 2 dpi groups and very low in 30 dpi groups. Objective magnification $\times 40$
Amin et al. (2012) reported that TLR2/9-MyD88-mediated signaling participates in intracerebral control of parasite load in the brain of T. brucei-infected mice (Amin et al. 2012). Moreover, Bafica et al. (2006) found that the same TLRs (2 and 9) cooperate in the control of infections by an intracellular parasite, such as T. cruzi. However, TLR2 and 9 but not TLR4, 5 , and 7 were involved in cerebral malaria (CM) infection

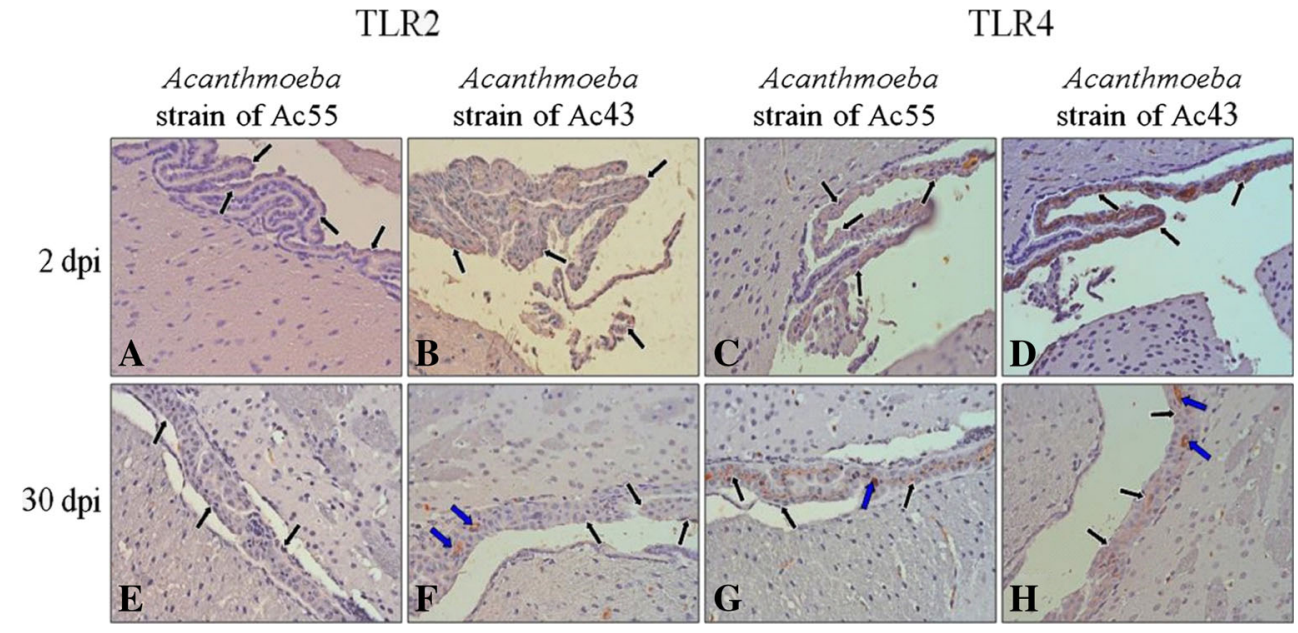


using Plasmodium berghei ANKA (PbA) (Coban et al. 2006). In contrast with the above results, Lepenies et al. (2008) demonstrated that the induction of $\mathrm{CM}$ is independent of TLR2, 4, and 9 caused by P. berghei ANKA infection. Moreover, human malaria is associated with higher expression levels of TLRs 1, 2, 4, and 8 and reduced levels of TLRs 3 and 5 (Ockenhouse et al. 2006; Loharungsikul et al. 2008). Additionally, other results suggested that TLR1, 2, 4, 6, and 9 are not independently essential for control of $T$. gondii infection. This result is in contrast with a study finding that TLR2 plays a role in the protective immunity against $T$. gondii infection in the lungs, but its protective function in this organ remains to be clarified (Mun et al. 2003). Importantly, Hitziger et al. (2005) suggested that different results may result from different strains, dose, and route of administration. Particularly, TLR2 is not an essential molecule for protective immunity to low-dose infection, but TLR2 is an essential molecule for protective immunity to high-dose infection of $T$. gondii ( 300 cysts or more) (Mun et al. 2003). A further study showed that TLR11-/- and TLR2/4 double knockout mice display relatively increased susceptibility to infection with a simultaneous decrease in IL-12 along with an increase in the number of brain cysts (Debierre-Grockiego et al. 2007; Yarovinsky 2008). It is worth noting that tachyzoite heat shock proteins and other partially purified tachyzoite preparations activate TLR4 and TLR2 (Aosai et al. 2002; Del Rio et al. 2004). Recently, a study found that TLR4 might be involved in inflammatory reactions of brain injury to chronic $T$. gondii infection of rats (Zhou et al. 2012). Another study, which involved a comprehensive analysis of TLR expression in the normal and parasite infected brain in a mouse model of neurocysticercosis (Mesocestoides corti), suggested a role for TLRs in the interplay of immune cells and CNS cells during infection. Above study indicated that TLRs were differentially distributed among various CNS cell types upon infection, e.g., TLR2 was localized to nervous tissue cells, particularly astrocytes, but TLR4 was localized to microglia and neurons (Mishra et al. 2006). Additionally, among all TLRs, TLR2 expression was induced first and was substantially upregulated in the brain during murine neurocysticercosis (Mishra et al. 2009). Moreover, the results of Gundra et al. (2011) demonstrated that TLR2-mediated responses help to mitigate not only CNS pathology but also mortality due to infection in murine NCC.

In conclusion, the alternative in the level of expression of TLR2 and TLR4 may imply the role of the innate immune system during parasitic infection. A family of proteins called TLRs plays an important role in the induction of inflammatory cytokines during infection, such as by parasites. Increased levels of TLR 2 and TLR4 mRNA expression in infected mice suggested the involvement of these TLRs in the recognition of Acanthamoeba PAMPs.
Open Access This article is distributed under the terms of the Creative Commons Attribution 4.0 International License (http:// creativecommons.org/licenses/by/4.0/), which permits unrestricted use, distribution, and reproduction in any medium, provided you give appropriate credit to the original author(s) and the source, provide a link to the Creative Commons license, and indicate if changes were made.

\section{References}

Acosta C, Davies A (2008) Bacterial lipopolysaccharide regulates nociception expression in sensory neurons. J Neurosci Res 86: 1077-1086

Akira S, Uematsu S, Takeuchi O (2006) Pathogen recognition and innate immunity. Cell 124:783-801

Amin DN, Vodnala SK, Masocha W, Sun B, Kristensson K, Rottenberg E (2012) Distinct Toll-like receptor signals regulate cerebral parasite load and interferon $\alpha / \beta$ and tumor necrosis factor $\alpha$-dependent Tcell infiltration in the brains of Trypanosoma brucei-infected mice. J Infect Dis 205:320-332

Aosai F, Chen M, Kang HK, Mun HS, Norose K, Piao LX, Kobayashi M, Takeuchi O, Akira S, Yano A (2002) Toxoplasma gondii-derived heat shock protein HSP70 functions as a B cell mitogen. Cell Stress Chaperones 7:357-364

Bafica A, Santiago HC, Goldschmid R, Ropert C, Gazzinelli RT, Sher A (2006) Cutting edge: TLR9 and TLR2 signaling together account for MyD88-dependent control of parasitemia in Trypanosoma cruzi infection. J Immunol 177:3515-3519

Barker J, Brown MR (1994) Trojan horses of the microbial world: protozoa and the survival of bacterial pathogens in the environment. Microbiology 140:1253-1259

Booton GC, Visvesvara GS, Byers TJ, Kelly DJ, Fuerst PA (2005) Identification and distribution of Acanthamoeba species genotypes associated with nonkeratitis infections. J Clin Microbiol 43:16891693

Bowman CC, Rasley A, Tranguch SL, Marriott I (2003) Cultured astrocytes express toll-like receptors for bacterial products. Glia 43:281291

Bsibsi M, Ravid R, Gveric D, van Noort JM (2002) Broad expression of Toll-like receptors in the human central nervous system. J Neuropathol Exp Neurol 61:1013-1021

Chandra D, Naik S (2008) Leishmania donovani infection downregulates TLR2-stimulated IL-12p40 and activates IL-10 in cells of macrophage/monocytic lineage by modulating MAPK pathways through a contact-dependent mechanism. Clin Exp Immunol 154: 224-234

Chavarria A, Alcocer-Varela J (2004) Is damage in central nervous system due to inflammation? Autoimmun Rev 3:251-260

Coban C, Ishii KJ, Uematsu S, Arisue N, Sato S, Yamamoto M, Kawai T, Takeuchi O, Hisaeda H, Horii T, Akira S (2006) Pathological role of Toll-like receptor signaling in cerebral malaria. Int Immun 19:67-79

Corsaro D, Feroldi V, Saucedo G, Ribas F, Loret JF, Greub G (2009) Novel Chlamydiales strains isolated from a water treatment plant. Environ Microbiol 11:188-200

Creagh EM, O'Neil LA (2006) TLRs, NLRs and RLRs: a trinity of pathogen sensors that co-operate in innate immunity. Trends Immunol 27:352-357

Cursons RT, Brown TJ, Keys EA, Moriarty KM, Till D (1980) Immunity to pathogenic free-living amoebae: role of cell-mediated immunity. Infect Immun 29:408-410

Dabbagh K, Lewis DB (2003) Toll-like receptors and T-helper-1/T-helper-2 responses. Curr Oppin Infect Dis 16:199-204

Debierre-Grockiego F, Campos MA, Azzouz N, Schmidt J, Bieker U, Resende MG, Mansur DS, Weingart R, Schmidt RR, Golenbock 
DT, Gazzinelli RT, Schwarz RT (2007) Activation of TLR2 and TLR4 by glycosylphosphatidylinositols derived from Toxoplasma gondii. J Immunol 179:1129-1137

Del Rio L, Butcher BA, Bennouna S, Hieny S, Sher A, Denkers EY (2004) Toxoplasma gondii triggers myeloid differentiation factor 88-dependent Il-12 and chemokine ligand 2 (monocyte chemo attractant protein 1) responses using distinct parasite molecules and host receptors. J Immunol 172:6954-6960

Dyková I, Kostka M, Wortberg F, Nardy E, Pecková H (2010) New data on aetiology of nodular gill disease in rainbow trout, Oncorhynchus mykiss. Folia Parasitol (Praha) 57:157-163

Egan CE, Sukhumavasi W, Butcher BA, Denkers EY (2009) Functional aspects of Toll-like receptor/MyD88 signalling during protozoan infection: focus on Toxoplasma gondii. Clin Exp Immunol $156: 17-24$

Ferrante A, Abell TJ (1986) Conditioned medium from stimulated mononuclear leukocytes augments human neutrophil-mediated killing of a virulent Acanthamoeba sp. Infect Immun 51:607-617

Ferrante A, Rowan-Kelly B (1983) Activation of the alternative pathway of complement by Acanthamoeba culbertsoni. Clin Exp Immunol $54: 477-485$

Gaze WH, Morgan G, Zhang L, Wellington EM (2011) Mimivirus-like particles in acanthamoebae from sewage sludge. Emerg Infect Dis 17:1127-1129

Geisen S, Fiore-Donno AM, Walochnik J, Bonkowski M (2014) Acanthamoeba everywhere: high diversity of Acanthamoeba in soils. Parasitol Res 113:3151-3158

Gieryng H, Gieryng R, Pirog Z (1993) Zmiany histologiczne w plucach myszy wywołane doświadczalnym zarażaniem pełzakami z grupy "limax". Wiad Parazytol 39:367-372

Gundra UM, Mishra BB, Wong K, Teale JM (2011) Increased disease severity of parasite-infected TLR2-/- mice is correlated with decreased central nervous system inflammation and reduced numbers of cells with alternatively activated macrophage phenotypes in a murine model of neurocysticercosis. Inf Immun 79:2586-2596

Hitziger N, Dellacasa I, Albiger B, Barragan A (2005) Dissemination of Toxoplasma gondii to immunoprivileged organs and role of Toll/ interleukin-1 receptor signaling for host resistance assessed by in vivo bioluminescences imaging. Cell Microbiol 7:837-848

Hoebe K, Jannssen E, Beutler B (2004) The interface between innate and adaptive immunity. Nat Immunol 5:971-974

Kasprzak W, Mazur T, Rucka A (1974) Studies on some pathogenic strains of free-living amoebae isolated from lakes in Poland. Ann Soc Belg Med Trop 54:351-357

Khan NA (2006) Acanthamoeba: biology increasing importance in human health. FEMS Microbiol Rev 30:564-559

Kielian T, Esen N, Bearden ED (2005) Toll-like receptor 2 (TLR2) is pivotal for recognition of $S$. aureus peptidoglycan but not intact bacteria by microglia. Glia 49:567-576

Kosik-Bogacka DI, Wojtkowiak-Giera A, Kolasa A, BaranowskaBosiacka I, Lanocha N, Wandurska-Nowak E, Gutowska I, Salamatin R, Jagodziński PP (2014) Hymenolepis diminuta: Analysis of the expression of Toll-like receptor genes and protein (TLR3 and TLR9) in the small and large intestines of rats. Exp Parasitol 145:61-67

Kosik-Bogacka DI, Wojtkowiak-Giera A, Kolasa A, CzernomysyFurowicz D, Lanocha N, Wandurska-Nowak E, Salamatin R, Jagodziński PP (2013) Hymenolepis diminuta: analysis of the expression of Toll-like receptor genes (TLR2 and TLR4) in the small and large intestines of rats. Part II. Exp Parasitol 135:437-445

Kosik-Bogacka DI, Wojtkowiak-Giera A, Kolasa A, Salamatin R, Jagodziński PP, Wandurska-Nowak E (2012) Hymenolepis diminuta: analysis of the expression of Toll-like receptor genes (TLR2 and TLR4) in the small and large intestines of rats. Exp Parasitol 130:261-266
Krishnegowda G, Hajjar AM, Zhu J, Douglass EJ, Uematsu S, Akira S, Woods AS, Gowda DC (2005) Induction of proinflammatory responses in macrophages by the glycosylphosphatidylinositols of Plasmodium falciparum: cell signaling receptors, glycosylphosphatidylinositol (GPI) structural requirement, and regulation of GPI activity. J Biol Chem 280:8606-8616

Laflamme N, Soucy G, Rivest S (2001) Circulating cell wall components derived from gram-negative, not gram-positive, bacteria cause a profound induction of the gene-encoding Toll-like receptor 2 in the CNS. J Neurochem 79:648-657

Layland LE, Rad R, Wagner H, da Costa CU (2007) Immunopathology in schistosomiasis is controlled by antigen-specific regulatory $\mathrm{T}$ cells primed in the presence of TLR2. Eur J Immunol 37:2174-2184

Leow-Dyke S, Allen C, Denes A, Nilsson O, Maysami S, Bowie AG, Rothwell NJ, Pinteaux E (2012) Neuronal toll-like receptor 4 signalling induces brain endothelial activation and neutrophil transmigration in vitro. J Neuroinflammation 9:230

Lepenies B, Cramer JP, Burchard GD, Wagner H, Kirsching CJ, Jacobs T (2008) Induction of experimental cerebral malaria is independent of TLR2/4/9. Med Microbiol Immunol 197:39-44

Loharungsikul S, Troye-Blomberg M, Amoudruz P, Pichyangkul S, Yongvanitchit K, Looareesuwan S, Mahakunkijcharoen Y, Sarntivijai S, Khusmith S (2008) Expression of toll-like receptors on antigen-presenting cells in patients with Falciparum malaria. Acta Trop 105:10-15

Mafra CS, Carrijo-Carvalho LC, Chudzinski-Tavassi AM, Taguchi FM, Foronda AS, Carvalho FR, de Freitas D (2013) Antimicrobial action of biguanides on the viability of Acanthamoeba cysts and assessment of cell toxicity. Invest Ophthalmol Vis Sci 54:6363-6372

Marciano-Cabral F, Cabral GA (2003) Acanthamoeba spp. as agents of disease in humans. Clin Microbiol Rev 16:273-307

Marciano-Cabral F, Toney DM (1998) The interaction of Acanthamoeba spp. with activated macrophages and with macrophage cell lines. J Eukaryot Microbiol 45:452-458

Martinez AJ, Visvesvara GS (1997) Free-living, amphizoic and opportunistic amebas. Brain Pathol 7:583-598

McClellan K, Howard K, Mayhew E, Niederkorn J, Alizadeh H (2002) Adaptive immune responses to Acanthamoeba cysts. Exp Eye Res 75:285-293

Medzhitov R (2001) Toll-like receptors and innate immunity. Nat Rev Immunol 1:135-145

Mishra BB, Gundra UM, Teale JM (2009) Toll-like receptors in CNS parasitic infections. Curr Top Microbiol Immunol 336:83-104

Mishra BB, Mishra PK, Teale JM (2006) Expression and distribution of Toll-like receptors in the brain during murine neurocysticercosis. $\mathrm{J}$ Neuroimmunol 181:46-56

Mun HS, Aosai F, Norose K, Chen M, Piao LX, Takeuchi O, Akira S, Ishikura H, Yano A (2003) TLR2 as an essential molecule for protective immunity against Toxoplasma gondii infection. Int Immunol 15:1081-1087

Nagyova V, Nagy A, Janecek S, Timko J (2010) Morphological, physiological, molecular and phylogenetic characterization of new environmental isolates of Acanthamoeba spp. from the region of Bratislava, Slovakia. Biologia 65:81-91

Nicholas KB, Nicholas HB Jr, Deerfield DWI (1997) GeneDoc: analysis and visualization of genetic variation. EMBNET News 4:1-22

Niyyati M, Lorenzo-Morales J, Rezaie S, Rahimi F, Mohebali M, Maghsood AH, Motevalli-Haghi A, Martín-Navarro CM, Farnia S, Valladares B, Rezaeian M (2009) Genotyping of Acanthamoeba isolates from clinical and environmental specimens in Iran. Exp Parasitol 121:242-245

Ockenhouse CF, Hu WC, Kester KE, Cummings JF, Stewart A, Heppner DG, Jedlicka AE, Scott AL, Wolfe ND, Vahey M, Burke DS (2006) Common and divergent immune response signaling pathways discovered in peripheral blood mononuclear cell gene expression 
patterns in presymptomatic and clinically apparent malaria. Infect Immun 74:5561-5573

Olson JK, Miller SD (2004) Microglia initiate central nervous system innate and adaptive immune responses through multiple TLRs. J Immunol 73:3916-3924

Ospelt C, Gay S (2010) TLRs and chronic inflammation. Int J Biochem Cell Biol 42:495-505

Qvarnstrom Y, Nerad TA, Visvesvara GS (2013) Characterization of a new pathogenic Acanthamoeba species, A. byersi sp., isolated from a human with fatal amoebic encephalitis. J Eukaryot Microbiol 60: 626-633

Roach JC, Glusman G, Rowen L, Kaur A, Purcell MK, Smith KD, Hood LE, Aderem A (2005) The evolution of vertebrate Toll-like receptors. Proc Natl Acad Sci U S A 102:9577-9582

Rolls A, Shechter R, London A, Ziv Y, Ronen A, Levy R, Schwartz M (2007) Toll-like receptors modulate adult hippocampal neurogenesis. Nat Cell Biol 9:1081-1088

Rucka A (1974) Picture of histopathological changes in the brain and lung of mice infected with pathogenic free-living amoebae. Ann Parasitol 20:247-250

Scheid P, Schwarzenberger R (2012) Acanthamoeba spp. as vehicle and reservoir of adenoviruses. Parasitol Res 111:479-485

Scheid P, Zöller L, Pressmar S, Richard G, Michel R (2008) An extraordinary endocytobiont in Acanthamoeba sp. isolated from a patient with keratitis. Parasitol Res 102:945-950

Schroeder JM, Booton GC, Hay J, Niszl IA, Seal DV, Markus MB, Fuerst PA, Byers TJ (2001) Use of subgenic 18S rDNA PCR and sequencing for generic and genotypic identification of Acanthamoeba from human cases of keratitis and from sewage sludge. J Clin Microbiol 39:1903-1911

Soto-Arredondo KJ, Flores-Villavicencio LL, Serrano-Luna JJ, Shibayama M, Sabanero-Lopez M (2014) Biochemical and cellular mechanisms regulating Acanthamoeba castellanii adherence to host cells. Parasitol 141:531-541

Stewart GL, Kim I, Shupe K, Alizadeh H, Silvany R, McCulley JP, Niederkorn JY (1992) Chemotactic response of macrophages to Acanthamoeba castellanii antigen and antibody-dependent macrophage-mediated killing of the parasite. J Parasitol 78:849-855

Stewart GL, Shupe K, Kim I, Silvany RE, Alizadeh H, McCulley JP, Niederkorn JY (1994) Antibody-dependent neutrophil-mediated killing of Acanthamoeba castellanii. Int J Parasitol 24:739-742

Takeda K, Kaisho T, Akira S (2001) Toll-like receptors. Annu Rev Immunol 21:335-376

Tang SC, Arumugam TV, Xu X, Cheng A, Mughal MR, Jo DG, Lathia JD, Siler DA, Chigurupati S, Ouyang X, Magnus T, Camandola S, Mattson MP (2007) Pivotal role for neuronal Toll-like receptors in ischemic brain injury and functional deficits. Proc Natl Acad Sci U S A 104:13798-13803
Thomas V, Loret JF, Jousset M, Greub G (2008) Biodiversity of amoebae and amoebae-resisting bacteria in a drinking water treatment plant. Environ Microbiol 10:2728-2745

Tu Z, Portillo JA, Howell S, Bu H, Subauste CS, Al-Ubaidi MR, Pearlman E, Lin F (2011) Photoreceptor cells constitutively express functional TLR4. J Neuroimmunol 230:183-187

Tuon FF, Amato VS, Bacha HA, Al Musawi T, Duarte MI, Neto VA (2008) Toll-like receptors and leishmaniasis. Infect Immun 76: 866-872

van der Kleij D, Latz E, Brouwers JF, Kruize YC, Schmitz M, Kurt-Jones EA, Espevik T, de Jong EC, Kapsenberg ML, Golenbock DT, Tielens AG, Yazdanbakhsh M (2002) A novel host-parasite lipid cross-talk. Schistosomal lyso-phosphatidylserine activates toll-like receptor 2 and affects immune polarization. J Biol Chem 277: 48122-48129

van der Kleij D, van der Biggeelaar AH, Kruize YC, Retra K, Fillie Y, Schmitz M, Kremsner PG, Tielens AG, Yazdanbakhsh M (2004) Responses to Toll-like receptor ligands in children living in areas where schistosome infections are endemic. J Infect Dis 189:1044-1051

Visvesvara GS, Moura H, Schuster FL (2007) Pathogenic and opportunistic free-living amoebae: Acanthamoeba spp., Balamuthia mandrillaris, Naegleria fowleri, and Sappinia diploidea. FEMS Immunol Med Microbiol 50:1-26

Visvesvara GS, Shoff ME, Sriram R, Booton GC, Crary M, Fuerst PA, Hanley CS, Garner MM (2010) Isolation, morphologic, serologic and molecular identification of Acanthamoeba T4 genotype from the liver of a Temminck's tragopan (Tragopan temminckii). Vet Parasitol 170:97-200

Yarovinsky F, Zhang D, Andersen JF, Bannenberg GL, Serhan CN, Hayden MS, Hieny S, Sutterwalla FS, Flavell RA, Ghosh S, Sher A (2005) TLR11 activation of dendritic cells by a protozoan profiling-like protein. Science 308:1626-1629

Yarovinsky F (2008) Toll-like receptors and their role in host resistance to Toxoplasma gondii. Immunol Lett 119:17-21

Year H, Zamfir O, Bourcier T, Ancelle T, Batellier L, Dupouy-Camet J, Chaumeil C (2007) Comparison of PCR, microscopic examination and culture for the early diagnosis and characterization of Acanthamoeba isolates from ocular infections. Eur J Clin Microbiol Infect Dis 26:221-224

Year H, Zamfir O, Bourcier T, Viscogliosi E, Noël C, Dupouy-Camet J, Chaumeil C (2008) The genotypic characterisation of Acanthamoeba isolates from human ocular samples. Br J Ophthalmol 92:1139-1141

Zhou YH, Wang SS, Yang J, Tao JP, Xu YL, Huang YZ, Gao Q (2012) Expression of Toll-like receptor 4 in brain tissue of chronic Toxoplasma gondii infection rats and its effect on brain injury. Zhongguo Xue Chong Bing Fang Zhi Za Zhi 24:58-61 